This item has been removed at the request of the author and is no longer available on this site. Please access it from:

http://www.enterprisingcompetencies.com/uploads/1/5/9/7/15971972/individualizing_entreprene urship_education.pdf 


\section{Autonomy as the Guiding Aim of Entrepreneurship Education}

Van Gelderen, Marco

2010

http://hdl.handle.net/10179/9764

22/04/2023 - Downloaded from MASSEY RESEARCH ONLINE 